\title{
Cost-effectiveness of minimally invasive sacroiliac joint fusion [Corrigendum]
}

Cher DJ, Frasco MA, Arnold RJ, Polly DW. Clinicoecon Outcomes Res. 2016;8:1-14.

The authors would like to make a correction to the Disclosure statement. The corrected statement is as follows:

Daniel J Cher is an SI-BONE employee. Renee JG Arnold and Melissa A Frasco are employees of Quorum Consulting, hired by SI-BONE to help prepare and evaluate the cost-utility model. David Polly is an investigator in clinical research studies sponsored by SI-BONE but has no financial interest in the company. The authors report no other conflicts of interest in this work.
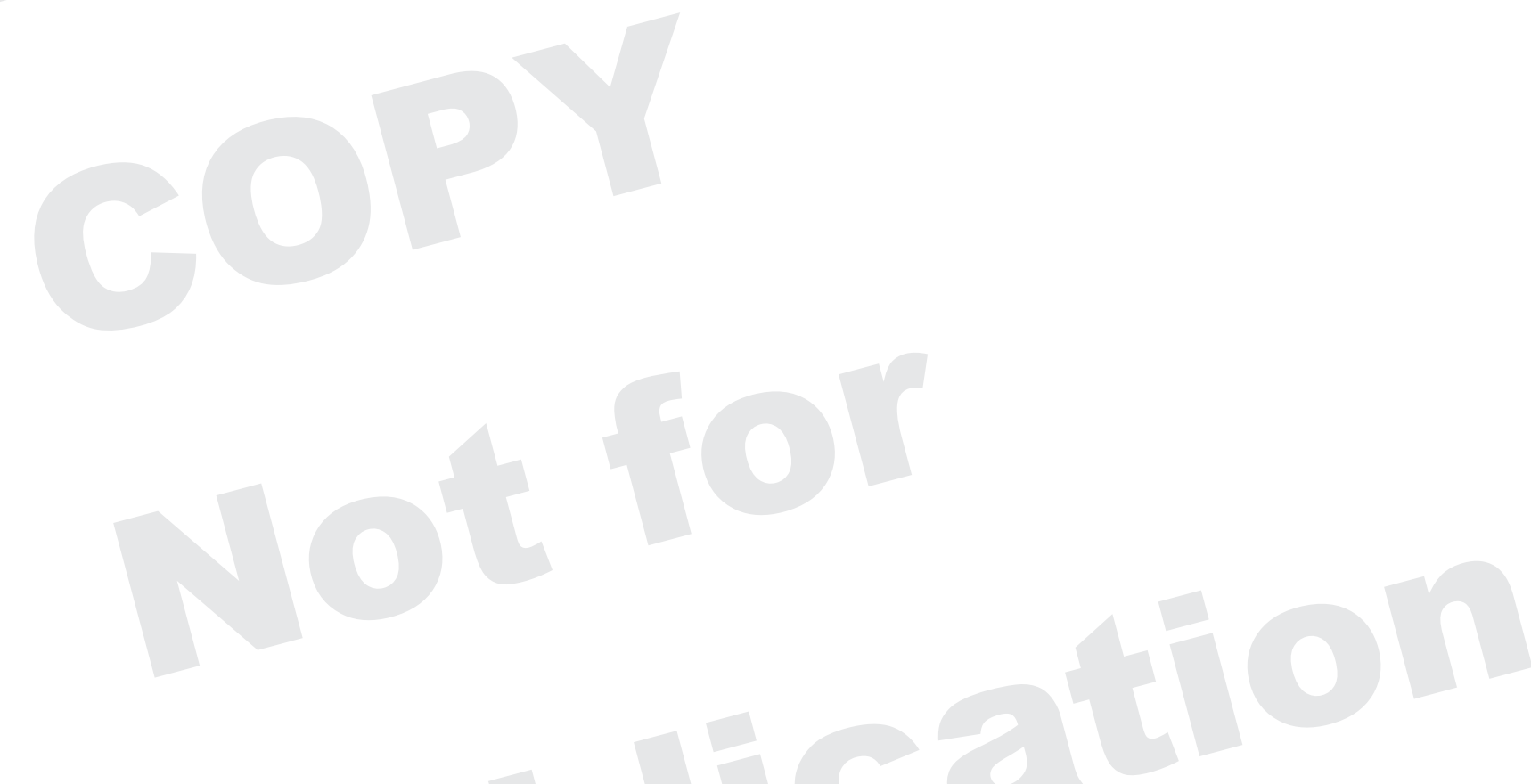

ClinicoEconomics and Outcomes Research

Dovepress

\section{Publish your work in this journal}

ClinicoEconomics and Outcomes Research is an international, peerreviewed open-access journal focusing on health technology assessment, pharmacoeconomics and outcomes research in the areas of diagnosis, medical devices, and clinical, surgical and pharmacological intervention. The economic impact of health policy and health systems

organization also constitute important areas of coverage. The manuscript management system is completely online and includes a very quick and fair peer-review system, which is all easy to use. Visit http://www.dovepress.com/testimonials.php to read real quotes from published authors.

Submit your manuscript here: https://www.dovepress.com/clinicoeconomics-and-outcomes-research-journal 